\title{
UNIVERSALISMO, RELATIVISMO E DIREITOS HUMANOS: UMA REVISITA CONTINGENTE*
}

Jayme Benvenuto

Com a afirmação de Norberto Bobbio (1992, p. 24), segundo a qual o problema fundamental dos direitos do homem contemporaneamente não é tanto o de justificá-los, ou seja, uma questão filosófica, mas o de protegê-los, uma questão política, o jurista e filósofo italiano quis pôr um ponto final num antigo debate. Pelo menos desde Antígona, a peça de Sófocles datada de 444 a.C., a discussão em torno da justificação do que se pode chamar modernamente de "direitos humanos" é um ponto de tensão na teoria e na prática sobre o tema. A heroína de Sófocles, após descumprir a ordem do rei-tio Creonte, procedendo ao enterro com todas as honras de seu irmão Polinices, sucumbe diante da força da lei dos homens. Não sem antes justificar a desobediência à ordem do rei de deixar o corpo de Polinices ser consumido pelos abutres pelo crime de sublevação contra o regime:

\footnotetext{
* As ideias desenvolvidas neste artigo foram apresentadas originalmente na aula inaugural ministrada pelo autor no Programa de Pós-graduação em Direitos Humanos da Universidade Federal de Pernambuco, em 13 de março de 2013. O artigo incorpora estudos realizados no período do pós-doutorado, na Universidade de Notre Dame, Indiana, EUA, sob os auspícios da Fundação Fulbright, em 2011.
} 
[...] não foi decisão de Zeus; e a Justiça, a deusa que habita com as divindades subterrâneas, jamais estabeleceu tal decreto entre os humanos; tampouco acredito que tua proclamação tenha legitimidade para conferir a um mortal o poder de infringir as leis divinas, nunca escritas, porém irrevogáveis; não existem a partir de ontem, ou de hoje; são eternas, sim!. Decretos como o que proclamaste, eu, que não temo o poder de homem algum, posso violar sem merecer punição dos deuses! (Sófocles, 2003, p. 96).

Mas fiquemos com este único exemplo da Antiguidade para seguir o ensinamento do professor aposentado da Universidade Federal de Pernambuco, Luciano Oliveira (2004), que, em artigo memorável, intitulado "Não Fale do Código de Hamurabi! A pesquisa sócio-jurídica na pós-graduação em direito", nos diz que não precisamos voltar a tempos remotos para abordar um tema da atualidade. De 118 fato, muitas vezes a referência a Hamurabi (e outras fontes da Antiguidade), como um marco do passado, é absolutamente desnecessária, se não por impropriedade, como nas justificações de todas as situações de direitos humanos em relação a uma referência de brutalidade, como é o caso do Código de Hamurabi, por um distanciamento histórico, o que nos torna obsoletos em termos metodológicos. Temos tanto o que observar no tempo presente que o apego ao passado é despropositado. A lembrança de Antígona, aqui, cumpre o papel de demonstrar que o debate é antigo, não mais que isso.

Pularei, então, Prometeu, a Ilíada, a Odisseia, a Lei das Doze Tábuas, o Talmude, a Bíblia, o Alcorão. Pularei as Cruzadas, Joana D’Arc, São Sebastião, nosso Tiradentes, até mesmo a primeira e a segunda guerras mundiais. Outras "Antígonas" têm tido a sua tragédia vivida com talvez maior rigor nos nossos tempos, sobretudo se consideramos que, ao repetirem a história à exaustão, as práticas contempo- 
râneas adquirem uma impertinente dramaticidade. O jornalismo, a literatura, o cinema e outras formas de arte contemporâneas têm trazido à luz situações que deixam nossas consciências históricas perplexas. Mencionarei aqui algumas situações vexatórias ocorridas nas últimas décadas em diversas partes do mundo.

Em entrevista ao programa de televisão da $A B C$ "World News Tonight with Peter Jennings”, durante os difíceis dias do conflito étnico na ex-Iugoslávia, nos anos de 1990, uma testemunha declarava aterrorizada: "Eu vi com meus próprios olhos Tadic bater em prisioneiros, atirá-los em óleo quente, forçá-los a castrar uns aos outros, bater-lhes tão severamente até matá-los"1 (Perry, 1997, p. 470)². Em matérias denominadas "Letters from Bosnia", publicados na revista The New Yorker, e que ficaram mundialmente famosas por revelarem a crueldade calculada dos sérvios, o jornalista David Rieff demonstra sua perplexidade diante do que viu na ex-Iugoslávia:

Um homem muçulmano em Bosansi Petrovac [...] [foi] forçado a morder o pênis de um companheiro muçulmano... Se você disser que um homem não é humano, mas que ele parece com você, e que a única maneira de identificar esse demônio é fazê-lo arrear as calças - homens muçulmanos são circuncizados, enquanto os sérvios não - provavelmente esse seria um passo curto, psicologicamente, para cortar seu pênis... Nunca houve uma campanha de limpeza étnica na qual não tenha havido sadismo sexual (Rieff, 1992, p. 82).

O conflito étnico entre os tutsis e os hutus ocorrido à mesma época em Ruanda dá razão a Rieff. Após o genocídio

\footnotetext{
1 Dusko Tadic foi julgado e condenado a vinte anos de prisão pelo Tribunal Penal Internacional ad hoc para a ex-Iugoslávia pela prática de crimes contra a humanidade, graves violações às convenções de Genebra e crimes de guerra.

2 Todas as traduções neste artigo foram feitas pelo autor.
} 
ruandês de 1994, outro jornalista, Jean Hatzfeld, embrenhou-se pelo país em que cerca de 800 mil pessoas foram retalhadas até a morte com o objetivo de entender e registrar o que ali ocorreu, ocasião em que captou a seguinte declaração de um certo Pancrace:

À noite, e até mesmo nas noitadas de antigamente, volta e meia o matador pensava: "Olha só esses tutsis, como são altos e esguios. Por isso é que são tão orgulhosos e nos consideram gente subalterna. Por isso é que as mulheres deles são tão apreciadas”. Assim, quando chegou a hora dos massacres, se um matador de maus bofes agarrava nos bambuais uma vítima um pouco alta, podia muito bem quebrar suas pernas, na altura dos tornozelos, por exemplo, e fazer a mesma coisa nos braços, e a deixava cortada e mais curta sem lhe dar um golpe fatal. Mesmo que a vítima não fosse tão alta, bastava ser mulher (Hatzfeld, 2005, p. 153).

Bem longe dali, a atriz Lucélia Santos registrou em filme a trágica situação do povo maubere, em 2000, um ano após o Timor Leste haver sido destruído com a participação do governo indonésio e o abandono da comunidade internacional (Timor, 2001). Como não lembrar da mesma dor sentida pelas mães e avós da Praça de Maio, na Argentina, que foram às ruas durante a ditatura militar dos anos de 1970-1980 denunciar o assassinato, a tortura e o desaparecimento de seus filhos e netos? No Brasil, recentemente se organizou o Movimento Mães de Maio, similar ao argentino, só que composto por mulheres que choram e exigem respostas do poder público para os filhos mortos pela Polícia Militar.

A luta delas (e deles), como a das mães e avós argentinas, é a mesma de Antígona, há cerca de 2.500 anos, contra o poder despótico. Na Grécia Antiga, como nos países latino-americanos de poucas décadas atrás ou em qualquer 
outro lugar do mundo de hoje, as justificativas variam, mas estão sempre presentes para o que se pode chamar de afirmações ou violações aos direitos humanos.

Não foi à toa que ao adotar uma declaração sobre direitos humanos, no âmbito da ONU, em 1948, os seus idealizadores resolveram vinculá-la inexoravelmente à ideia de universalidade: Declaração Universal dos Direitos Humanos. A universalidade presente no título do documento tinha a intenção de demonstrar seu alcance global, portanto, para além dos âmbitos nacionais. Mas também registrava a pretensão de validade inquestionável, eterna, irrevogável, no dizer de Antígona.

Desde sempre, o debate é colocado em termos de existência ou não de uma natureza humana. Em importante artigo intitulado "Are human rights universal? The relativist challenge and related matters", publicado em 1997, Michael Perry inicia a abordagem fazendo referência a um documento da Igreja Católica: a encíclica Veritatis Splendor, de autoria do Papa João Paulo II. Naquele documento, o papa reitera o entendimento em torno do conceito de natureza humana com um ataque ao relativismo.

Se de fato o homem é um ser indefinidamente maleável, totalmente plástico, sem quaisquer estruturas mentais inatas, nem quaisquer necessidades intrínsecas de um caráter cultural ou social, então ele está sujeito ao "comportamento formatável" pela autoridade estatal, pelo gestor corporativo, pelo tecnocrata ou pelo comitê central (Perry, 1997, p. 470).

A encíclica papal sustenta-se na "'existência de normas objetivas de moralidade' válidas para todos os povos do presente e do futuro, assim como para os do passado" (Perry, 1997, p. 470). Trata-se, pois, da velha ideia de que existe algo no homem que transcende as culturas e este algo é precisamente a natureza humana, que deve servir como medida cultural e a 
"condição a garantir que o homem não se torne um prisioneiro de nenhuma de suas culturas, mas alcance sua dignidade pessoal vivendo de acordo com a verdade profunda do seu ser" (Perry, 1997, p. 470).

Nessas breves palavras da encíclica estão contidos, explícita e implicitamente, os principais elementos do debate milenar a respeito da justificação dos direitos humanos: natureza humana, verdade e cultura. Está contido sobretudo um elemento que se esconde por trás das palavras e conceitos construídos: o medo de que o ser humano (ou o homem, para ser consistente com a antiguidade do debate) perca completamente os limites diante da inexistência de uma autoridade transcendente capaz de regular sua vida e limitar ou mesmo impedir as chamadas desvirtualidades.

Perry segue a trilha dada pela encíclica papal afirmando que a ideia de direitos humanos apresenta dois desafios:

[...] a premissa ou reclamo de que todo ser humano é sagrado (inviolável etc.) e o reclamo seguinte é o de que, pelo fato de que todo ser humano ser sagrado (e dadas todas as outras informações relevantes), certas escolhas devem ser feitas e certas escolhas rejeitadas; em particular, certas coisas não devem ser feitas a qualquer ser humano e certas coisas devem ser feitas para todos os seres humanos (Perry, 1997, p. 470).

O ponto fundamental do artigo de Perry, decorrente da ideia de que todo ser humano é sagrado, ao qual ele se refere como desafios, é precisamente o de que há certas coisas que não devem ser feitas a ninguém e outras que devem ser feitas a todas as pessoas. Perry tem clareza da seriedade do debate, não apenas em relação ao primeiro desafio, mas sobretudo em relação ao segundo. De fato, é mais fácil chegar à definição do que não deve ser feito a ninguém (não matar, não torturar, não estuprar, não discriminar, não 
prender ilegalmente, não praticar limpeza étnica, não fazer desaparecerem pessoas), que do que deve ser feito a todos os seres humanos.

A respeito das coisas que devem ser feitas a todas as pessoas surgem difíceis questões, como é o caso da circuncisão feminina ou fanado de mulher ou extirpação do clitóris, expressões que assumem diferentes conotações de acordo com o entendimento que se tem do fenômeno cultural. A expressão circuncisão feminina aproxima a prática daquela utilizada em relação aos homens, considerando-a parte da cultura de um povo, da mesma forma que fanado de mulher, expressão usada em países africanos de língua portuguesa. Ao se referir à extirpação do clitóris, aí está presente toda a aversão à prática cultural, em relação à qual o interlocutor deve provavelmente advogar seu combate por via da lei ou da mudança dos costumes.

Mesmo em relação às coisas que não devem ser feitas a todos os seres humanos, Perry parece desconsertado com as situações levantadas por autores relativistas que revelam a possibilidade de que algumas pessoas sentem prazer, por exemplo, em serem torturadas em contextos de práticas sexuais às quais denominemos apenas como heterodoxas. Para esses autores, a condição de submissão voluntária a essas práticas absolve o praticante de qualquer possibilidade de ser submetido a um processo judicial pela prática do crime de tortura.

Os desafios colocados por Perry para defender o universalismo, ao contrário do que ele próprio poderia imaginar, revelam a dificuldade que essa perspectiva tem para continuar se afirmando nos tempos atuais, marcados pelo subjetivismo e pelo respeito às mais diversas formas de expressão.

Por outro caminho segue Jack Donnelly (2003), para quem o relativismo cultural seria um fato inegável, mas revelaria problemas sobretudo no plano da proteção internacional dos direitos humanos. Esse autor está preocupado com 
o que pensamos ao relacionar a ideia de relativismo cultural com as práticas terríveis que ocorrem todos os dias em diversas partes do mundo: seria o caso de as ignorarmos por entendermos que são culturalmente orientadas? A saída por ele apresentada é a aproximação universalista em relação aos direitos humanos reconhecidos internacionalmente. Argumenta que "a cultura coloca apenas um modesto desafio para o contemporâneo universalismo normativo dos direitos humanos" (Donnelly, 2003, pp. 89-92). Se os relativistas culturais radicais têm uma tendência a priorizar os julgamentos internos de uma sociedade, considerando a cultura a única fonte de validade para os direitos, e os universalistas radicais tenderiam a dizer que a cultura é irrelevante para a validação de direitos, Donnelly encontra proteção na normativa internacional de direitos humanos, o que o coloca no campo do normativismo universal.

Para Joaquín Herrera Flores (2009, p. 119), ao desen124 volver sua concepção complexa e relacional dos direitos humanos, o universalismo que nos pode interessar nos tempos atuais consiste em garantir a todos os seres humanos a "possibilidade de lutar, plural e diferenciadamente, pela dignidade humana". A partir dessa compreensão, Herrera Flores (2009, p. 119, nota 76) constrói a imagem do diamante ético ${ }^{3}$ para dar visibilidade ao processo de construção e afirmação dos direitos humanos. O diamante ético é uma figura tridimensional que está sempre em movimento, "um sistema integrado de cristais que se formou com o passar do tempo por superposições de materiais que, ao final, convergem na maravilhosa figura da joia" (Herrera Flores, 2009, p. 120). Os materiais a que Herrera Flores (2009, p. 120) se

\footnotetext{
3 A figura do diamante ético de Herrera Flores (2009, p. 119, nota 76), em suas palavras, "tem seu precedente no texto de Wendy Griswold, Cultures and societies in a changing world, Pine Forge Press, Thousand Oaks, 1994, que desenvolve a figura do 'diamante cultural' como base para um entendimento global e interativo da cultura".
} 
refere para falar de direitos humanos são o "resultado de lutas que se sobrepõem com o passar do tempo e que são impulsionadas tanto por categorias teóricas (linha vertical de nosso diamante) como por categorias práticas (linha horizontal da figura)". O diamante ético de Herrera Flores indica a existência de segmentos que se agregam uns aos outros, dentro de um longo processo de desenvolvimento histórico, no qual

[...] todos os componentes estão estreitamente imbricados e interconectados [...] e não se pretende esgotar a quantidade de elementos que comporão a figura global do diamante. Podemos acrescentar outros elementos se isso nos parecer adequado e se pudermos justificar de forma prática e teórica essa inclusão. Para nós, aqueles existentes neste momento constituem o mínimo para compreender os direitos humanos em toda sua complexidade (Herrera Flores, 2009, p. 120).

Nessa perspectiva, pode-se afirmar que os sistemas internacionais de direitos humanos, compostos de tratados e órgãos, integram o diamante ético que constituem os direitos humanos. O que significa que não podemos desprezar o que nos serve em termos contextuais porque agrega significado à nossa existência, mas devemos estar abertos a novos elementos que venham a compor o diamante ético dos direitos humanos, incluindo possíveis novas interpretações a respeito de problemas que existem há muito tempo, embora podendo ter certo grau de invisibilidade.

\section{Contingência, ironia e direitos humanos}

A limitação da perspectiva teórica de Herrera Flores é o grau de idealização que ele atribui ao mundo dos direitos humanos, embora se apresentando como realista. Esse equívoco, aliás, é recorrente em muitos realistas nominais, incapazes 
que foram de fazer o salto proporcionado pela virada linguística. $\mathrm{O}$ que poderia ser mais significativo de certo idealismo que a imagem translúcida de um diamante ético para representar os direitos humanos? A própria ideia de representação da realidade coloca-o no campo de um pensamento tradicionalíssimo de construção do conhecimento. Daí ser necessário, a meu juízo, ampliar o seu horizonte com a visão exposta pelo filósofo norte-americano Richard Rorty, para quem a ideia de viver numa sociedade democrática é central no campo da política. Seu conhecimento a respeito do processo de conhecimento humano permitirá construir uma visão sentimental dos direitos humanos como parte da política em que os direitos são negociados.

A definição em torno do que é uma sociedade justa ou democrática - para a qual a produção legal e jurisprudencial pode concorrer - depende do contexto histórico em que as pessoas vivem e da capacidade que elas têm de 126 estabelecer um diálogo aberto com os contemporâneos, de modo a convencê-los de que sua perspectiva é mais adequada ou mesmo melhor, num dado momento, em comparação com o que foi ou é praticado. Melhor no sentido "de conter mais do que consideramos bom e menos do que consideramos mau” (Rorty, 1999, p. 28). Melhor, portanto, em termos contingentes.

$\mathrm{Na}$ perspectiva rortyana, a democracia é um regime compatível com a criação de pessoas diferentes, cujo objetivo não é fazer a vontade da maioria, mas possibilitar que as pessoas, incluindo as minorias, também tenham seus desejos alcançados. Sua visão da democracia é, assim, a da construção de nós mesmos. Rorty fala de um mundo construído pelos seres humanos que se constroem no dia a dia. Prefere dizer que "a esperança vem antes do conhecimento", na medida em que aquela nos permite projetar um futuro em que os habitantes da Terra possam construir "a melhor versão de nós mesmos" (Rorty, 1999, p. 2). 
Essa perspectiva é considerada melhor por Rorty por permitir a construção de um sentido de comunidade com base na consciência sobre a capacidade de diálogo dos seres humanos como única fonte para permitir que as pessoas sigam em frente. A seu ver, essa consciência pode ajudá-las a sair do campo do confronto para o do diálogo, desde que assim elas queiram.

Em vez de se buscar um fundamento absoluto para a existência, seria melhor, segundo Rorty, que as pessoas se apegassem à única diretriz válida para a comunidade de que participam: aquela que permite que a conversa entre interpretações concorrentes aconteça. "O objetivo próprio da filosofia não é descobrir a verdade objetiva, mas manter a discussão entre essas diferentes interpretações", interpreta Stanley Grenz (1996, p. 158) a respeito do pensamento de Rorty.

A tese de Rorty é que simplesmente as pessoas não têm outra alternativa, se se quiserem comprometidas com a democracia, além de começar a se engajar em redes sociais nas quais possam se comunicar e construir identificações. Dessa forma, não se estaria descrevendo uma sociedade de anjos, diz o autor, mas presumindo um compromisso democrático com o diálogo em sociedades que se proponham a ser democráticas.

A perspectiva do autor é a da esperança na política como o campo de produção cultural que pode permitir transformações que façam as pessoas contingentemente melhores. Por isso, a preocupação não é com o futuro imediato, muito menos com soluções que possam ser estabelecidas em caráter permanente. $\mathrm{O}$ presente e o futuro próximo é o que constitui a preocupação de quem adota a perspectiva de uma justiça ou democracia contingente. $\mathrm{O}$ que se busca é estabelecer visões e modos capazes de tornar a existência humana melhor, de acordo com uma base de respeito em torno da qual as pessoas possam conversar. 
Vinculado a essa ideia de contingência, Rorty fala de um sentimentalismo que nada tem a ver com a moralidade tradicional ou o senso de obrigação moral, mas com amor, amizade, confiança e solidariedade social. Coisas, assim por dizer, mais simples. A seu ver, esse tipo de educação sentimental deixaria as pessoas menos tentadas a pensar a respeito de outras pessoas como quase-humanas, como Tadic fez com os muçulmanos, os hutus com os tutsis, os indonésios com os timorenses, os generais latino-americanos com os esquerdistas. O objetivo dessa noção é expandir a referência de expressões como "nosso tipo de pessoas" e "gente como a gente", frequentemente presentes nos discursos sociais (Grenz, 1996, p. 127). Adequa-se a ela apenas quem não quer aprofundar as diferenças que foram construídas historicamente. Em outras palavras, não seria a racionalidade que salvaria a humanidade já que se tem consciência de que pessoas dotadas de racionalidade são capazes de fazer 128 coisas terríveis. Como lembra Rorty.

Para muitas pessoas brancas, até muito recentemente, os negros simplesmente não contavam. Para os cristãos, até o século XVII, os pagãos não contavam. Para os nazistas, os judeus não contavam. Para muitos homens em países cuja renda anual média está abaixo de 4 mil dólares, a maioria das mulheres continua não contando. Onde quer que rivalidades tribais e nacionais se coloquem como importantes, os membros das tribos e nações rivais não contam (Grenz, 1996, p. 127).

Rorty insiste que, para que as pessoas "sejam melhores com os negros, os homens com as mulheres, os sérvios com os muçulmanos ou os héteros com os gays" (Grenz, 1996, p. 127), não é útil apelar para os valores comuns de uma humanidade idealizada. Isso em razão da percepção de que algumas pessoas se sentem "ofendidas com a sugestão de tratar pessoas que elas não reconhecem como humanas como se 
fossem humanas" (Grenz, 1996, p. 127). Para Rorty, muitas pessoas, particularmente aquelas que não se deixaram tocar pelo Iluminismo simplesmente não admitem a ideia de igualdade na prática e para todos. Essas pessoas pensam em si mesmas como uma espécie ideal de seres humanos, à imagem de quem todas as outras devem se acomodar, além de uma espécie claramente definida enquanto exemplo de bondade em oposição às outras que devem ser rotuladas como particularmente más (Grenz, 1996, p. 128).

Para lidar com esse tipo de visão, Rorty apregoa apenas a sinceridade e certo sentimento de compaixão. Considera um progresso a crescente habilidade das pessoas para enxergar similaridades entre elas mesmas e outras pessoas muito distintas delas como um equilíbrio de diferenças. $\mathrm{E}$ a isso ele chama de "educação sentimental". Dessa forma, produz-se uma inversão na verdade do Iluminismo: os sentimentos passam a ser mais fortes que a razão.

Para Rorty, a melhor resposta para a questão sobre por que nós deveríamos nos preocupar com um estranho seria

Porque $e l a^{4}$ está naquela situação, longe de casa, entre estranhos ou porque ela poderia se tornar sua nora ou porque sua mãe está aflita com a sua situação. [...] Esse progresso trouxe-nos a um momento da história humana no qual é plausível [...] dizer que o fenômeno dos direitos humanos é um "fato do mundo". Esse fenômeno pode ser apenas um pequeno ponto, mas pode marcar o começo de um novo tempo, no qual o estupro coletivo possa acarretar uma resposta forte quando acontecer a mulheres ou a homens, quando acontecer a estrangeiros ou a pessoas como nós (Rorty, 1993, p. 134; grifo no original).

\footnotetext{
4 Observe-se que Rorty utiliza, provocativa e afirmativamente, o pronome pessoal no feminino para descrever situações que dizem respeito, indistintamente, a homens e mulheres. Com essa atitude, ele certamente queria deixar ironicamente frustrados e irritados ou, no mínimo, pensativos, os homens (e certas mulheres) que fazem pouco caso das preocupações com a linguagem de gênero.
} 
A frase final da citação anterior deixa claro que Rorty não está para brincadeira com a visão tradicional universalista-idealista, mas também com os machos humanos tradicionais, universalistas interessados na manutenção do status quo que só lhes favorece.

Rorty, aqui seguindo Marilyn Frye, está preocupado com a vida em sociedade em que muitas pessoas, embora vivendo dentro de um padrão aceitável de comportamento, são culpabilizadas por terem nascido mulheres, gays ou negros. Isso acontece não apenas por uma conjuntural desvantagem socioeconômica, mas também "pelo mesmo motivo que faz com que crianças nobres tenham um inefável horror de se imaginar tendo nascido em lares não nobres" (Rorty, 1998, p. 226). A linguagem androcêntrica, na visão do autor, tem suas conexões com a linguagem econômica, numa clara indicação de que no mundo atual existe uma linguagem do opressor e uma linguagem do oprimido, cuja distância pre130 cisa ser diminuída e em algum tempo superada. A forma indicada para alcançar esse novo momento é construindo uma nova linguagem que, com o tempo, passaria a tomar parte da linguagem que todo o mundo fala, misturando-se com as formas da linguagem tradicional.

$\mathrm{O}$ vislumbre trazido pelas feministas às quais Rorty chama provocativamente de proféticas, como Catharine MacKennon e Marilyn Frye, é não apenas de um novo ser para as mulheres, mas para toda a sociedade:

Elas vislumbram uma sociedade na qual a distinção masculinofeminino não é mais de muito interesse. As feministas que também são pragmatistas veem a formação de tal sociedade como a remoção de construtos sociais e a restauração das coisas como sempre deveriam ser (Rorty, 1998, pp. 226-27).

Trata-se de uma concepção política compatível com a ideia de que a cultura está em permanente movimento e, 
se as pessoas forem persistentes para melhorar suas vidas, segundo parâmetros que venham a definir no diálogo intracultural, poderão melhorar a própria cultura: desfazer proibições, estabelecer outras, na medida em que se seja capaz de justificá-las.

Quando chego nesse ponto, muitos já se perguntaram: quem deve ter o poder de definir o que é adequado para uma sociedade? Nós mesmos. Num debate aberto do qual todos possam participar, o que não significa negar que, por força da forma como a política é feita e das circunstâncias atuais, poderá haver algum grau de imposição. Afinal, assim são formuladas e redefinidas as culturas, não sejamos ingênuos.

No artigo intitulado "Human rights, rationality and sentimentality", publicado em 1993, Rorty aborda especificamente o tema dos direitos humanos de um ponto de vista poderoso. Sua visão contingente permite analisar o tema comparando o comportamento dos assassinos e estupradores sérvios da Bósnia do genocídio do início dos anos de 1990 com a escravidão perpetrada nos Estados Unidos alguns séculos atrás: “Como os sérvios, o Sr. Jefferson não pensava a respeito de si mesmo como violando direitos humanos" (Rorty, 1998, p. 221); "Os sérvios, os moralistas, Jefferson e os muçulmanos negros, todos usam o termo 'homem' para significar 'pessoas como nós'. Eles pensam que a linha que separa os humanos e os animais não é simplesmente a linha que divide os bípedes sem pena e os demais" (Rorty, 1993, pp. 111-34).

Ao afirmar isso, Rorty queria dizer que se estava fazendo o mesmo tipo de distinção que os cruzados faziam em relação aos então denominados "cachorros infiéis" (infidel dogs) e que os muçulmanos negros fazem em relação aos chamados "demônios de olhos azuis" (blue-eyed-devils). Com isso, Rorty reitera que a humanidade não foi salva pelas ideias iluministas. Seja nos Bálcãs, seja nas democracias ricas e seguras do 
Ocidente, onde se pensa a respeito dos torturadores e estupradores sérvios como eles se sentem em relação às suas vítimas muçulmanas: "eles estão mais para animais que nós", na opinião de Rieff (1992, pp. 112-13).

A partir dessa consideração, Rorty passa a expor o que considera serem as distinções paradigmáticas que os seres humanos fazem entre eles próprios e outras situações. A primeira é a distinção entre os seres humanos e os animais (como na Bósnia); a segunda é a distinção entre adultos e crianças (Pessoas ignorantes e surpersticiosas, dizemos, são como crianças; Os negros, costumavam dizer os brancos nos Estados Unidos e na África do Sul, são como crianças.). Quando a distinção diz respeito às mulheres, segundo Rorty, há maneiras mais simples de excluí-las de uma humanidade de fato, como quando se utiliza o termo homem como sinônimo para ser humano, através do que os homens expressam o sentimento médio mas132 culino de agradecimento por não terem nascido mulher (repetido ingenuamente também por mulheres que assumem a forma de pensar masculina), assim como o temor da mais terrível das degradações: a femininização. Já a terceira forma de desumanização de alguém, do ponto de vista tradicional, é ser não masculino (non male), cujas possibilidades mais severas são quando alguém nasce sem o pênis, quando tem seu pênis retirado, por qualquer razão, ou quando alguém é penetrado por um pênis (Rorty, 1993, pp. 111, 114).

O que Rorty buscava demonstrar com essas distinções era que a filosofia tradicional não foi bem-sucedida para explicar a essência do ser humano, e mais, que o Iluminismo, que se pretendeu libertador, não foi capaz de mudar essa forma de pensar e agir, razão pela qual muitos estudiosos e pessoas comuns ainda refletem tais pensamentos. Declarando que o debate perdeu o foco no século XX, Rorty (1993, p. 114) propõe negar significado 
à questão "O que é a natureza?" e, em seu lugar, colocar "O que podemos fazer por nós mesmos?" 5

Então Rorty pega emprestado do jurista e filósofo argentino Eduardo Rabossi o termo "cultura de direitos humanos", utilizado num artigo intitulado "Human rights naturalized", no qual Rabossi (apud Rorty, 1993, pp. 117-18) "argumenta que os filósofos deveriam pensar nessa como uma nova cultura, surgida do mundo pós-holocausto". Para Rorty (1993, pp. 116-17), deve-se "parar de tentar se colocar atrás ou embaixo dos fatos, parar de tentar detectar e defender os chamados "pressupostos filosóficos'" e apenas imaginar que o mundo mudou, que as bases tradicionais sob as quais os direitos humanos foram estabelecidos foram ultrapassadas, diante do que as pessoas podem seguir mudando.

O que o pragmatismo rortyano faz aqui é apelar à efetividade do argumento segundo o qual "Desde que não foi feito nenhum trabalho útil quanto à insistência numa suposta natureza humana a-histórica, é porque provavelmente não haverá nenhuma natureza, ou pelo menos nada na natureza para as nossas escolhas morais" (Rorty, 1993, p. 119). Esse autor, no entanto, não quer simplesmente descartar a tradição platônica e kantiana, mas expressar gratidão a tais filósofos "não por terem descoberto verdades, mas por terem profetizado utopias cosmopolitas - utopias que podem ter falhado nos detalhes, mas que não teriam permitido que chegássemos até aqui se não as tivéssemos ouvido" (Rorty, 1993, pp. 121-22).

Ele acredita na possibilidade de produzir gerações melhores, mais tolerantes, prósperas, respeitadoras das

\footnotetext{
5 Rorty continua: "Muitos homens que foram estuprados estão convencidos de que sua masculinidade, e portanto sua humanidade, foi retirada. Como os racistas que descobrem possuir ancestralidade judaica ou negra, eles podem cometer suicídio por pura vergonha, vergonha por não ser mais o tipo de ser bípede sem pena que conta como humano.”
} 
diferenças como forma de se alcançar a utopia iluminista. Mas ele não acredita que seja uma boa ideia encorajar as pessoas a categorizar como "irracionais" as pessoas intolerantes (Rorty, 1993, p. 128). E é assim porque, a seu ver, "as crenças das pessoas más não são mais ou menos 'irracionais' que nossas crenças de que raça, religião, gênero e preferência sexual são moralmente irrelevantes" (Rorty, 1993, p. 128). Nesse sentido, seria melhor ensinar-lhes que as pessoas más não são menos irracionais, nem menos esclarecidas que as pessoas boas que respeitam as outras. O problema das pessoas más, para Rorty, é que elas não tiveram tanta sorte na vida por tratar como irracionais todas aquelas pessoas lá fora, que estão adotando comportamentos que elas consideram inadequados. Se elas pensam nos outros como pessoas que estão privadas da verdade ou do conhecimento moral, seria melhor e mais eficaz pensar nelas como pessoas privadas de duas coisas mais 134 concretas: segurança e compaixão. Não é o caso de afirmar que Rorty não atribui qualquer fundamento aos direitos humanos por confiar mais em outras narrativas e gêneros de discurso, conforme indica Portales (2007, p. 61). Sua justificativa é simplesmente contingente, tem que ser construída e reconstruída nas conversas políticas a cada dia.

\section{Contingência à brasileira}

Pelo que até o momento foi exposto, evidente está que a perspectiva universalista tradicional relaciona-se com uma visão absolutista (ou absolutizante, na melhor das hipóteses) dos direitos humanos, derivada de noções teológicas, cosmológicas ou racionais; enquanto a perspectiva relativista é condicionada por noções culturalistas que entendem os direitos humanos como históricos e espacialmente localizados.

Herrera Flores, Jack Donnelly e Richard Rorty, com variações, embora declarando a insuficiência do universa- 
lismo tradicional para seguir justificando os direitos humanos, demonstram a necessidade de adotarmos um padrão universal histórico, no caso de Herrera Flores, contemporaneamente normativo, no caso de Donnelly, ou contingente, no caso de Rorty. Com isso, eles querem dizer que alguma âncora deve ser lançada ao mar para que as pessoas não corram o risco de adentrar o mar bravio, com todas as consequências que isso poderia trazer. Histórica e contingentemente, foram construídas algumas salvaguardas das quais não se pode abrir mão, pelo menos hoje, enquanto outras precisam ser criadas para melhorar o padrão daquilo que se denomina respeito aos direitos humanos. O caminho segue sendo lutar, no plano da política, para defender ideias que se opõem a outras. Não se tem a verdade. Mas há bons motivos e bons argumentos para dizer que o melhor caminho está à frente.

Não é possível pura e simplesmente aceitar o convite cheio de boas intenções de Bobbio ao esquecimento da justificação dos direitos humanos em prol de sua proteção. Isso porque não há como esquecer a história de atrocidades e violações aos direitos humanos, tenham sido cometidas na Antiguidade, nas últimas décadas do século XX ou nos dias atuais, em qualquer lugar do mundo.

Entre as mais corriqueiras no nosso país, atualmente, dou destaque aos ataques do militar da reserva Jair Bolsonaro e do pastor Marco Feliciano, deputados federais brasileiros que têm feito declarações atentatórias aos direitos humanos.

O deputado federal Jair Bolsonaro fez as seguintes declarações num programa de tevê em relação às cotas raciais: "Eu não entraria em um avião pilotado por um cotista nem aceitaria ser operado por um médico desses. Indagado pela cantora Preta Gil, sobre o que ele faria se seu filho se apaixonasse por uma negra, disse em tom agressivo: 
Ô Preta, não vou discutir promiscuidade com quem quer que seja. Eu não corro esse risco. Meus filhos foram muito bem-educados e não viveram em ambiente como, lamentavelmente, é o teu. [...] Agora criaram a Frente Gay [na Câmara]. O que esse pessoal tem para oferecer? Casamento gay? Adoção de filhos? Dizer pra vocês, que são jovens, que se tiverem um filho gay é legal, vai ser o orgulho da família? Esse pessoal não tem nada para oferecer ${ }^{6}$.

Questionado no programa sobre como reagiria caso seu filho fosse usuário de drogas, Bolsonaro disse: "Daria uma porrada nele, pode ter certeza disso."7 Sobre a proposta de redução da maioridade penal, tendo em vista o suposto aumento da violência, o deputado comentou em entrevista em 8 de fevereiro de 2014: "A verdade é que as pessoas não aguentam essa violência que está aí. A culpa é da sociedade? Porra nenhuma. É o que eu falei para Benedita: 136 'adota e leva para casa esse vagabundo aí'." Mais recentemente, em 9 de dezembro de 2014, o deputado Bolsonaro foi acusado de agredir, nos mesmos termos já anteriormente praticados, a também deputada Maria do Rosário (PT-RS), ex-ministra dos Direitos Humanos durante o primeiro governo Dilma. Na ocasião, ele reiterou que não estupraria Maria do Rosário porque "ela não merece". Ao subir à tribuna da Câmara para atacá-la, o deputado dizia: "Não saia, não, Maria do Rosário, fique aí. Fique aí, Maria do Rosário. Há poucos dias você me chamou de estuprador no Salão Verde e eu falei que eu não a estuprava porque você não merece. Fique aqui para ouvir." O discurso era uma referência a declarações da

6 Disponível em: <http://mtv.uol.com.br/memo/o-deputado-federal-jair-bolsonaro-se-complica-com-declaracoes-homofobicas-e-racistas-na-tv $>$. Acesso em: 12 mar. 2014.

7 Disponível em: <http://mtv.uol.com.br/memo/o-deputado-federal-jair-bolsonaro-se-complica-com-declaracoes-homofobicas-e-racistas-na-tv $>$. Acesso em: 12 mar. 2014.

8 Disponível em: <http://exame.abril.com.br/brasil/noticias/bolsonaro-explica-o-que-entende-por-direitos-humanos-leia>. Acesso em: 10 fev. 2015. 
deputada sobre o Dia Mundial dos Direitos Humanos e os trabalhos da Comissão Nacional da Verdade ${ }^{9}$.

O deputado Marco Feliciano (PSC-SP), eleito, em 7 de março de 2013, Presidente da Comissão de Direitos Humanos e Minorias (CDHM) da Câmara dos Deputados, declarou entre outras coisas que aids era o "câncer gay" e que os descendentes de africanos seriam pessoas amaldiçoadas: "A maldição que Noé lança sobre seu neto, Canaã, respinga sobre o continente africano, daí a fome, pestes, doenças, guerras étnicas!" ${ }^{10}$.

No twitter, ao longo do mês de março de 2013, o deputado Marco Feliciano declarou que "A podridão dos sentimentos dos homoafetivos levam [sic] ao ódio, ao crime, à rejeição" ${ }^{11}$. No mesmo período, no facebook, o deputado destacou que

Estamos vivenciando a maior de todas as batalhas contra a família brasileira, e a igreja está sendo bombardeada pelas mentiras insinuadas por grupo de bandeira LGBT (gays, lésbicas, bissexuais e travestis), que planeja dividir e destruir nossas igrejas e famílias, usando a política e a discriminação como arma ${ }^{12}$.

As críticas do então presidente da CDHM alcançam, na realidade, o direito das mulheres. Em entrevista para o livro Religiões e política: uma análise da atuação dos parlamentares evangélicos sobre direitos das mulheres e LGBTs no Brasil,

9 Disponível em: <http://congressoemfoco.uol.com.br/noticias/pgr-vai-analisar-declaracoes-de-jair-bolsonaro/>. Acesso em: 10 fev. 2015.

10 Disponível em: <http://www.cartacapital.com.br/politica/pastor-marco-feliciano-e-eleito-para-presidir-comissao-de-direitos-humanos $/$ ?utm_source=dlvr. it\&utm_medium=twitter>. Acesso em: 12 mar. 2014.

${ }_{11}$ Disponível em: <http://exame.abril.com.br/brasil/album-de-fotos/15-tuites-polemicos-do-pastor-e-deputado-marco-feliciano $>$. Acesso em: 10 fev. 2015.

12 Disponível em: <http://exame.abril.com.br/brasil/album-de-fotos/15-tuites-polemicos-do-pastor-e-deputado-marco-feliciano>. Acesso em: 10 fev. 2015. 
de Christina Vital e Paulo Victor ${ }^{13}$, divulgada pelo $O$ Globo on-line, em 20 de março de 2013, o deputado critica as reivindicações do movimento feminista e afirma ser contra as suas lutas porque elas podem conduzir a uma sociedade predominantemente homossexual. O livro ao qual o jornal se refere contém a declaração extensiva do deputado:

Quando você estimula uma mulher a ter os mesmos direitos do homem, ela querendo trabalhar, a sua parcela como mãe começa a ficar anulada, e, para que ela não seja mãe, só há uma maneira que se conhece: ou ela não se casa, ou mantém um casamento, um relacionamento com uma pessoa do mesmo sexo, e que vão gozar dos prazeres de uma união e não vão ter filhos. Eu vejo de uma maneira sutil atingir a família; quando você estimula as pessoas a liberarem os seus instintos e conviverem com pessoas do mesmo sexo, você destrói a família, cria-se uma sociedade onde só tem homossexuais, você vê que essa sociedade tende a desaparecer porque ela não gera filhos.

Em entrevista disponível no youtube, postada em 27 de setembro de 2013, o deputado Feliciano, ao mesmo tempo que atacou a cantora Daniela Mercury, que anunciara o casamento com outra mulher, demonstrou incômodo com o vídeo produzido pelo canal Porta dos Fundos, intitulado "Oh Meu Deus", no qual os humoristas anunciam a volta de Jesus Cristo durante os trabalhos preparatórios de um parto. A provocação ao estilo rortyano - embora os seus autores nem devam conhecer o autor - tem o sentido de colocar pessoas que pensam como os deputados Bolsonaro e Feliciano no lugar que eles colocam os outros, invertendo-se os papéis. Se os deputados têm verdades absolutas a defender,

\footnotetext{
${ }^{13}$ Publicado em 2013 pela Fundação Heinrich Böll e Instituto de Estudos da Religião (Iser), Rio de Janeiro.
} 
os personagens dos quadros humorísticos do canal Porta dos Fundos têm descrenças humoradas a expor ${ }^{14}$. Não à toa, o vídeo "Oh Meu Deus" foi comentando com desprezo pelo pastor Feliciano: "Esperei pra ver se tinha um humor inteligente, uma crítica, mas não tinha. Puro vandalismo. Pegaram a fé cristã e jogaram no lixo." 15

Em outras palavras, no lugar de se reagir com adjetivações como "pânico moral" para o comportamento dos deputados, conforme sugere um analista ${ }^{16}$, a atitude irônica tem o poder de afirmar a igualdade dos polos do debate. Embora dizendo-se indignada com as declarações de Feliciano, Hildete Pereira de Melo, professora da UFF e pesquisadora de relações de gênero e mercado de trabalho, reagiu de forma irônica.

Desde a invenção da pílula anticoncepcional, os casais heterossexuais podem manter vida sexual ativa sem que a gravidez ocorra. Atribuir aos homossexuais a responsabilidade pela destruição da família é um delírio. A destruição tem como culpado o homem, que sai de casa e abandona os filhos quando o relacionamento termina. É preciso entender que os filhos são responsabilidade do casal, e não apenas da mulher ${ }^{17}$.

O vídeo do grupo gay Põe na Roda, publicado no canal Catraca Livre, em 28 de novembro de 2014, provoca e ironiza ainda mais. Com o título "E se o seu filho se assumisse...?", um repórter aborda pessoas sobre como elas reagiriam se

\footnotetext{
${ }^{14}$ Disponível em: <http://www.youtube.com/watch?v=AYiSqyiVaA4>. Acesso em: 11 fev. 2015.

15 Disponível em: <https://www.youtube.com/watch?v=IoXVicbYwb4>. Acesso em: 10 fev. 2015.

${ }^{16}$ Disponível em: <http://oglobo.globo.com/brasil/marco-feliciano-diz-que-direitos-das-mulheres-atingem-familia-7889259>. Acesso em: 10 fev. 2015.

${ }^{17}$ Disponível em: <http://oglobo.globo.com/brasil/marco-feliciano-diz-que-direitos-das-mulheres-atingem-familia-7889259>. Acesso em: 10/02/2015.
} 
descobrissem que o filho era (como) Jair Bolsonaro, Marco Feliciano, Levy Fidelix, Ângela Bismarchi, o pastor Everaldo e a cantora Joelma. As reações, estudadas para fazer rir, provocar e refletir sobre os argumentos utilizados por seus defensores, inverte o mecanismo de indignação, colocando os defensores de posições divergentes em pé de igualdade, como a dizer: não há uma verdade absoluta para questões como as que estamos debatendo.

Ao perguntar o que a interlocutora faria se descobrisse que a filha era (como) Ângela Bismarchi, que acusou a tevê de "colocar gays nas novelas como se fosse normal", a resposta da entrevistada é: "Isso jamais aconteceria, inadmissível. Você acha isso normal?". Sobre a possibilidade de o entrevistado descobrir que o filho era (como) Bolsonaro, para quem ter filho gay seria falta de palmada, o interlocutor responde: "Dava uma palmada nele. Se o moleque começa a demonstrar desde cedo que vai se tornar um reacinha, tem 140 que dar uma palmada pra ele aprender o que é que é certo.” À pergunta sobre como reagiria se o filho fosse (como) o pastor Everaldo, o interlocutor responde: "Na minha família, eu não aceito um pastor Everaldo. [...] Na minha família, uma família de amor, de amizade, não dá pra ter uma pessoa preconceituosa como o pastor Everaldo.” Em relação a Joelma, que comparou a condição gay a uma droga, o entrevistado diz: "Olha, eu sou contra, muito, completamente contra. Eu sou contra o casamento entre Joelma e Chimbinha, não acho que isso é natural, a começar pela cor do cabelo deles. Sabe, eu acho que ser Joelma é um vício. [...] Eu tenho muitas amigas Joelmas, mas muitas conseguiram se recuperar, graças a Deus." Sobre Levy Fidelix, que se referiu ao aparelho excretor como não tendo capacidade de se reproduzir, a interlocutora ironiza acidamente: "Pelo amor de Deus, isso nunca iria acontecer porque eu pari meu filho, eu não caguei. [...] Meu filho fala pela boca e não pelo órgão excretor. E eu criei ele muito bem pra ele [não] ser preconceituoso desse jeito.” Em 
relação a Marco Feliciano, autor do projeto de lei da "Cura Gay", a entrevistada reage: "Eu acho que eu tentaria ajudar, internaria, amarraria à força. [...] Tem cura pra tanta coisa, tem cura pra homofobia também, se chama ensino fundamental completo."18

Da perspectiva rortyana, só posso dizer que os deputados Jair Bolsonaro e Marco Feliciano correspondem à revivificação de figuras de tempos antigos, assombradas com a existência pessoal e coletiva num mundo sem bússola e dividido em andares, identificados com o céu, a terra e o inferno. Feliciano e Bolsonaro ainda não entenderam que além da Terra existem outros mundos para os quais não temos como acessar qualquer explicação completa e definitiva, absoluta, portanto. Qualquer explicação já construída, no campo das religiões ou da ciência, está condicionada pela história e sujeita ao debate.

Bolsonaro e Feliciano, como figuras deslocadas alguns séculos no tempo para trás, nunca se deixaram tocar pelas ideias do Iluminismo, como igualdade, solidariedade e liberdade. Mas parece que o deslocamento histórico deles vai além do Iluminismo, já que também não conhecem ideias como respeito e tolerância. Podemos chamá-los apropriadamente de pré-cristãos. São dignos de pena porque, passados tantos séculos, eles não conseguiram acessar um padrão mínimo de respeito ao que entendemos como direitos humanos, ainda raciocinam como no tempo da escravidão. Sorte nossa que somos diferentes deles.

O ideal universalista, segundo o qual todos são iguais, não passa de uma construção social sujeita às intempéries colocadas por violadores de direitos humanos, como os estupradores da Bósnia, de Ruanda e do Timor Leste; e como os feitores do Congresso Nacional.

\footnotetext{
${ }^{18}$ Disponível em: <https://catracalivre.com.br/geral/cidadania/indicacao/e-se-o-seu-filho-se-assumisse-jair-bolsonaro/>. Acesso em: 10 fev. 2015.
} 


\section{Jayme Benvenuto}

é professor-adjunto da Universidade Federal da Integração Latino-Americana (Unila) no curso de Relações Internacionais e Integração.

\section{Bibliografia}

BOBBIO, N. 1992. A era dos direitos. Rio de Janeiro: Campus.

DONNELLY, J. 2003. Universal human rights in theory and practice. New York: Cornell University Press.

GRENZ, S. J. 1996. A primer on Postmodernism. Grand Rapids: William B. Eerdmans Publishing Company.

HATZFELD, J. 2005. Uma temporada de facões: relatos do genocídio em Ruanda. São Paulo: Companhia das Letras.

HERRERA FLORES, J. 2009. A (re)invenção dos direitos humanos. Florianópolis: Fundação Boiteux.

OLIVEIRA, L. 2004. "Não fale do Código de Hamurabi! A pesquisa sócio-jurídica na pós-graduação em direito". In: . Sua excelência o comissário e outros ensaios de sociologia jurídica. Rio de Janeiro: Letra Legal.

142 and related matters". Human Rights Quarterly, v. 19, n. 3, p. 470.

PORTALES, R. 2007. "Universalidad de los derechos humanos y crítica de las teorías de la naturaleza humana en el pragmatismo de Richard Rorty". Universitas - Revista de Filosofía, Derecho y Política, n. 5.

RIEFF, D. 1992. "Letter from Bosnia, 'Original Virtue, Original Sin'”. The New Yorker, Nov. 23.

RORTY, R. 1993. "Human rights, rationality and sentimentality". In: SHUTE, S.; HURLEY, S. On human rights: the Oxford Amnesty lectures. New York: Basic Books. . 1998. "Feminism and pragmatism". In: Truth and progress.

Cambridge: Cambridge University Press (Philosophical Papers, v. 3). . 1999. Philosophy and social hope. London: Penguin Books.

SÓFOCLES. 2003. Édipo Rei. Antígona. São Paulo: Martin Claret.

TIMOR Leste: o massacre que o mundo não viu. 2001. Direção: Lucélia Santos. São Paulo: Nock Produções.

VITAL, C.; VICTOR, P. 2013. Religião e política: uma análise da atuação de parlamentares evangélicos sobre direitos das mulheres e LGBTs no Brasil. Rio de Janeiro: Ed. Fundação Heinrich Böll e Instituto de Estudos da Religião (Iser). 


\section{UNIVERSALISMO, RELATIVISMO E DIREITOS HUMANOS: UMA REVISITA CONTINGENTE}

JAYME BENVENUTO

Resumo: Este artigo revisita o debate em torno do universalismo e do relativismo cultural aplicado aos direitos humanos, buscando atualizá-lo a partir de situações verificadas nas últimas décadas em certas partes do mundo, incluindo o Brasil. Assume a defesa do relativismo contingente sob a influência do filósofo norte-americano Richard Rorty. Conclui com a aplicação da perspectiva da educação sentimental, desenvolvida pelo filósofo citado, a recentes declarações dos parlamentares brasileiros Jair Bolsonaro e Marco Feliciano.

Palavras-chave: Direitos Humanos; Universalismo; Relativismo.

\section{UNIVERSALISM, RELATIVISM, AND HUMAN RIGHTS: A CONTIGENT REVISIT}

Abstract: This article revisits the debate on universalism and cultural relativism applied to human rights, seeking to upgrade it from situations that have been verified in recent decades in certain parts of the world, including Brazil. It assumes the defense of contingent relativism under the influence of the American philosopher Richard Rorty. It concludes with the application of the perspective of sentimental education, developed by the referred philosopher, in recent statements of Brazilian parliamentarians Jair Bolsonaro and Marco Feliciano.

Keywords: Human Rights; Universality; Relativism.

Recebido: 09/04/2013

Aprovado: 13/02/2014 